\title{
Ketepatan Waktu Pendistribusian Barang Pada Warehouse Management System di PT. CEVA Logistics Tahun 2019
}

\author{
Abi Prasidi ${ }^{1}$, Lis Lesmini ${ }^{2}$ \\ Institut Transportasi dan Logistik Trisakti \\ prasidi393@gmail.com ${ }^{1}$, lies.1969@yahoo.com ${ }^{2}$
}

\section{ARTICLE INFO}

\section{Article History}

Received : 2 Oktober 2019

Reviewed : 15 Oktober 2019

Published : 31 Oktober 2019

Available Online : 2 November 2019

\section{Keywords}

Warehouse

Management System

Produk Barang

Distribusi

\begin{abstract}
Ceva Logistics merupakan perusahaan logistik berbasis kontrak "pure play" terbesar di dunia, fokus pada 6 sektor yaitu otomotif, ban, electronik, fast moving consumer goods (FMCG), industrial, dan percetakkan serta media. Tujuan penelitian ini untuk mengetahui pengaruh sistem manajemen pergudangan terhadap kelancaran distribusi. Metode analisis data yang digunakan adalah Analisis Regresi Linear Sederhana, Analisis Koefisien Korelasi, Koefisien Penentu dan Uji Hipotesis (uji korelasi). Hasil analisis dan pembahasan menunjukan adanya hubungan antara sistem manajemen pergudangan terhadap kelancaran distribusi yang ditunjukan dengan persamaan garis regresi linier sederhana yaitu $\mathrm{Y}=3,94+0,84 \mathrm{X}$, artinya setiap perubahan satu satuan skor variabel $\mathrm{X}$, akan diikuti perubahan skor nilai $\mathrm{Y}$ sebesar 0,84 kali X pada konstanta 3,94. Hasil uji hipotesis menunjukan bahwa nilai thitung adalah sebesar 5,10 nilai ttabel adalah sebesar 1,701. Berarti thitung > ttabel, yaitu $5,10>1,71$, karena thitung lebih besar dari ttabel maka Ho ditolak dan Ha diterima. Artinya ada pengaruh yang signifikan dan kuat antara sistem manajemen pergudangan terhadap kelancaran distribusi
\end{abstract}

\section{PENDAHULUAN}

Dinamika pertumbuhan ekonomi global saat ini menuntut pelaku ekonomi yang bergerak dibidang apapun untuk dapat meningkatkan kemampuannya dalam menghadapi ketatnya persaingan, baik persaingan dibidang layanan penyedia jasa pergudangan dan jasa transportasi dalam ketepatan waktu mendistribusikan produk sampai ke tangan konsumen.

Latar permasalahan ini dimana proses pendistribusian barang yang masih belum tepat waktu di karenakan adanya warehouse management system yang masih belum mengikuti Standard Operation Procedure (SOP) dan pada Fungsi Manajemennya, seperti Perencanaan, Organisasi, Penggerakan dan Pengawasan.

PT. CEVA melayani perusahaan menengah dan besar di 26 negara dengan fokus pada 6 sektor yaitu: otomotif, ban, elektronik, fast moving consumer goods (FMCG), industrial dan percetakkan serta media kerap kali ditemukan adanya masalah pada saat pendistribusian barang.

Tujuan keberadaan gudang adalah untuk menyimpan produk sampai produk tersebut diminta oleh pelanggan.Aktivitas pergudangan pada umumnya meliputipenerimaan (receiving), pengalokasian (putaway), penyimpanan (storage), pemilihan (order picking), pengepakan (packaging), dan pengiriman (shipment).

\subsection{Jenis dan Sumber Data}

\section{Jenis Data}

- Data Kualitatif adalah data yang dihimpun berdasarkan cara-cara yang melihat suatu objek penelitian. Data semacam ini lebih melihat kepada proses daripada hasil karena didasarkan pada deskripsi proses dan bukan pada perhitungan matematis. Data yang diperoleh seperti jumlah barang yang disimpan digudang lebih banyak dari kapasitasnya. 
- Data Kuantitatif adalah data yang berbentuk angka atau bilangan. Sesuai dengan bentuknya serta data kuantitatif dapat diolah atau dianalisismenggunakan teknik perhitungan matematika atau statistika. Data yang diperoleh seperti pegawai yang sudah mematuhi SOP perusahaan sekitar $85 \%$.

\section{Sumber Data}

- Data Primer adalah data yang diperoleh langsung dari responden atas perusahaan yang disebut juga sebagai data asli atau data baru. Data diperoleh dengan melakukan observasi, wawancara dan penyebaran kuesioner. Data yang diperoleh seperti riset pada karyawan dan kepuasan pelanggan pada PT. CEVA Logistics.

- Data Sekunder adalah data yang diperoleh atau dikumpulkan dari berbagai sumber yang telah ada yang dapat digunakan sebagai dasar penunjang dalam menganalisis masalah-masalah yang menjadi pembahasan dalam karya ilmiah ini. Data sekunder yang diperoleh seperti data company profile, data administrative, dandatabase komersial perusahaan sebagai pemicu untuk memahami persoalan yang muncul dalam perusahaan.

\subsection{Populasi dan sampel}

\section{Populasi}

Menurut Sugiyono (2016: 90) populasi adalah generalisasi yang terdiri atas: obyek dan subyek dalam mengembangkan kualitas atau mutu dan karakteristik tertentu yang ditetapkan oleh peneliti untuk dipelajari dan ditarik kesimpulan. Dalam penelitian ini yang menjadi objek penelitian adalah seluruh karyawan divisi pergudangan atau warehouse PT. CEVA Logistics yang berjumlah 30 orang.

\section{Sampel}

Sampel adalah bagian dari jumlah dan karakteristik yang dimiliki oleh populasi tersebut Menurut Sugiyono (2016: 96) sampling jenuh adalah teknik penentuan sampel bila semua anggota populasi digunakan sebagai sampel. Populasi karyawan divisi warehouse sebanyak 30 orang, karena populasi kurang dari 100 maka teknik pengambilan sampel dengan sampling jenuh yang diambil keseluruhan dari populasi untuk sampel.

\section{KAJIAN PUSTAKA}

\subsection{Penelitian Sebelumnya}

\section{Analisis Sistem Distribusi}

Analisis Sistem Distribusi Logistik, Gerai Sistem Distribusi Logistik di Kota Semarang Putri Mutiara Bena (2015 : 1) Dwi PuspaSari, Eldimas Erdiansyah A Departemen Perencanaan Wilayah dan Kota, Universitas Dipenogoro

\section{Analisis Pelaksanaan Distribusi}

Analisis Pelaksanaan Distribusi penjualan Produk Percetakan Buku (Khusus Kantor Perwakilan oleh Dicky Febna (2015 : 1)

\subsection{Manajemen Logistik}

\section{Pengertian Manajemen Logistik}

Menurut Amin Widjaja Tunggal (2009 : 2) manajemen logistik merupakan bagian dari supply chain yang berfungsi untuk merencanakan, melaksanakan dan mengendalikan keefisienan dan keefektifan aliran dan penyimpanan barang, pelayanan dan informasi terkait dari titik permulaan (point of-origin) hingga titik konsumsi (point of-consumption) dalam tujuannya untuk memnuhi kebutuhan para pelanggan. 
Sedangkan menurut Kamus Terpopuler Transportasi dan Logistik (2012 : 85) manajemen logistik adalah proses yang secara strategis mengelola pengadaan, perpindahan dan penyimpanan material, suku cadang, persediaan barang jadi dan aliran informasi terkait, melalui organisasi dan kanal-kanal pemasarannya, dalam cara dimana keuntungan pada saat sekarang dan yang akan datang dimaksimalkan melalui pemenuhan pesanan yang berbiaya efektif.

\section{Tujuan Manajemen Logistik}

Untuk mendistribusikan produk (barang dan jasa) secara tepat, baik bahan, waktu, tempat dan pengiriman dengan kualitas produk yang terjamin, dengan biaya serendah mungkin untuk mencapai keuntungan perusahaan semaksimal mungkin, Ratih Hendayani (2011 : 20)

\subsection{Manajemen Pergudangan}

\section{Pengertian Gudang}

"Gudang adalah suatu tempat atau bangunan yang dipergunakan untuk menimbun, menyimpan barang, baik berupa bahan baku, barang setengah jadi, atau barang jadi” Willem Siahaya (2013 : 88)

Menurut Ricky Martono (2015 : 343) gudang adalah tempat penyimpanan sementara dan pengambilan inventory untuk mendukung kegiatan operasi bagi proses operasi berikutnya, ke lokasi distribusi, atau kepada konsumen akhir.

"Gudang (kata benda) adalah bangunan yang dipergunakan untuk menyimpan barang dagangan, pergudangan (kata kerja) ialah kegiatan menyimpan dalam gudang” John Warman (2016 : 5)

\section{Pengertian Manajemen Pergudangan}

Menurut Willem Siahaya (2013 : 88) manajemen pergudangan adalah bagian dari manajemen logistik dan Supply Chain Management, merupakan pengelolaan kegiatan menerima, menyimpan, merawat, mengirim dan menatausahakan barang pada suatu tempat tertentu.

\section{Jenis Gudang}

Jenis gudang menurut Ricky Martono (2015 : 351-352) dibedakan menjadi dua yaitu:

- Gudang Umum yaitu gudang tempat menyimpan inventory pada periode waktu yang panjang. Tujuannya untuk menjaga kondisi barang tetap baik sampai sampai saat barang digunakan. Fungsinya adalah menyimpan persediaan pada proses manufaktur. Kegiatan penanganan dan perpindahan barang di dalam gudang relatif sedikit. Jenis persediaan yang ditempatkan pada gudang umum biasanya persediaan untuk antisipasi dan fluktuasi.

- Gudang Distribusi yaitu gudang yang menerima barang dalam jenis dan jumlah beragam (bisa dari sumber yang beragam), menyimpan barang-barang tersebut, dan menyortir barang sesuai permintaan konsumen yang beragam. Peran dari gudang ini adalah proses penanganan dan pengiriman barang sesuai waktu yang disepakati, bukan menyimpan barang dalam waktu lama. Dengan demikian fungsi mendukung proses konsolidasi, break bulk, dan cross docking. Perbedaan gudang umum dan gudang distribusi secara garis besar adalah Gudang umum digunakan di proses manufaktur, sedangkan gudang distribusi mendukung proses konsolidasi break bulk, dan cross docking.

\section{Fungsi Gudang}

Ada beberapa fungsi utama dari gudang menurut Ricky Martono (2015 : 343) yaitu:

- Menyimpan barang untuk sementara waktu sampai menunggu giliran untuk diproses.

- Memantau pergerakan dan status barang.

- Meminimumkan biaya pergerakan barang, peralatan, dan karyawan.

- Menyediakan media komunikasi dengan konsumen mengenai barang.

- Titik penyeimbang aliran persediaan dan barang. 


\subsection{Warehouse Management System}

\section{Pengertian Warehouse Management System}

Warehouse Management System (WMS) adalah suatu sistem yang digunakan didalam pengelolaan yang mengatur proses penanganan barang semenjak dari penerimaan hingga pengirimannya. Seluruh proses dilakukan dengan mempergunakan suatu sistem tertentu dan biasanya dibantu dengan perangkat komputerisasi, pallet, forklift dan rak tinggi. Widiyanto (2011).

Sedangkan Warehouse Management System atau sistem manajemen pergudangan sendiri merupakan kunci utama dalam supply chain (rantai pasok), dimana yang menjadi tujuan utama adalah mengontrol segala proses yang terjadi didalamnya seperti shipping (pengiriman), receiving (penerimaan), putaway (penyimpanan), move (pergerakan) dan picking (pengambilan).

Dalam Warehouse Management System.

\section{METODE PENELITIAN}

\subsection{Alur Penelitian}

Alur penelitian ini akan dilakukan dengan melalui beberapa tahapan pelaksanaan, sebagaimana tertuang pada gambar berikut ini.

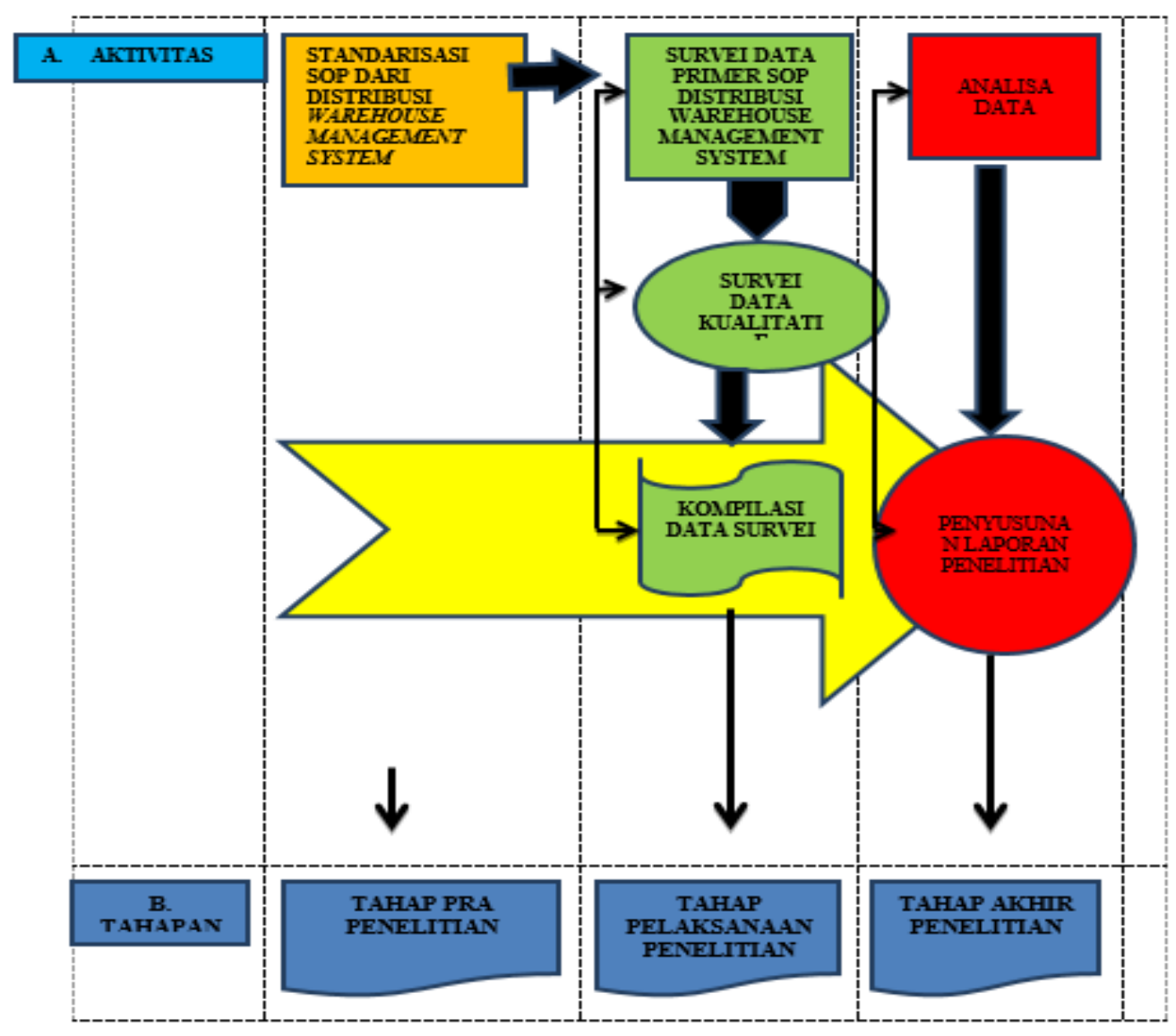

Alur ini sudah menjadi stadarisasi dalam penelitian ini untuk memudahkan penjabaran dan pembahasan untuk lebih runtun. 
Tabel 1. Hasil Kuesioner

\begin{tabular}{|c|c|c|c|c|c|c|}
\hline \multicolumn{2}{|c|}{ Pelayanan Sistem Manajemen Pergunangan } & $\begin{array}{c}\text { Sangat } \\
\text { Tidak } \\
\text { Setuju } \\
\end{array}$ & $\begin{array}{l}\text { Tidak } \\
\text { Setuju }\end{array}$ & $\begin{array}{c}\text { Ragu- } \\
\text { ragu }\end{array}$ & Setuju & $\begin{array}{l}\text { Sangat } \\
\text { Setuju }\end{array}$ \\
\hline 1 & $\begin{array}{l}\text { Menurut Anda, apakah PT Ceva Logistic } \\
\text { sudah memiliki kepekaan yang baik terhadap } \\
\text { keinginan masyarakat dan para pelanggannya? }\end{array}$ & 1 & 2 & 3 & 4 & 5 \\
\hline 2 & $\begin{array}{l}\text { Menurut Anda, apakah perusahaan transportasi } \\
\text { PT Ceva Logistic saat ini sudah dapat dengan } \\
\text { cepat memberikan pelayanan yang sesuai } \\
\text { dengan selera pelanggan? }\end{array}$ & 1 & 2 & 3 & 4 & 5 \\
\hline 3 & $\begin{array}{l}\text { Menurut Anda, apakah perusahaan PT Ceva } \\
\text { Logistic sudah tanggap dalam melayani } \\
\text { keinginan masyarakat untuk keamanan } \\
\text { terhadap armadanya? }\end{array}$ & 1 & 2 & 3 & 4 & 5 \\
\hline 4 & $\begin{array}{l}\text { Menurut Anda, apakah perusahaan sudah } \\
\text { tanggap terhadap kondisi persaingan dalam } \\
\text { industri logistic atau transportasi darat di } \\
\text { dalam negeri? }\end{array}$ & 1 & 2 & 3 & 4 & 5 \\
\hline 5 & $\begin{array}{l}\text { Menurut Anda, apakah perusahaan transportasi } \\
\text { dan logistic sudah secara rutin melakukan } \\
\text { pemantauan terhadap aktivitas pesaing ? }\end{array}$ & 1 & 2 & 3 & 4 & 5 \\
\hline 6 & $\begin{array}{l}\text { Menurut Anda, apakah perusahaan logistic } \\
\text { sudah berusaha beradaptasi dengan persaingan } \\
\text { perusahaan logistic lainnya di dalam negeri } \\
\text { yang dihadapi? }\end{array}$ & 1 & 2 & 3 & 4 & 5 \\
\hline 7 & $\begin{array}{l}\text { Menurut Anda, apakah setiap bagian } \\
\text { fungsional dalam perusahan logistic sudah } \\
\text { senantiasa melakukan hubungan kerjasama } \\
\text { secara intensif? }\end{array}$ & 1 & 2 & 3 & 4 & 5 \\
\hline 8 & $\begin{array}{l}\text { Menurut Anda, apakah setiap bagian } \\
\text { fungsional dalam perusahaan logistik sudah } \\
\text { senantiasa saling berbagi pengetahuan, } \\
\text { informasi, dan pengalaman? }\end{array}$ & 1 & 2 & 3 & 4 & 5 \\
\hline 9 & $\begin{array}{l}\text { Menurut Anda, apakah perusahaan logistic } \\
\text { umum/massal sudah berorientasi pada kinerja } \\
\text { keuangan? }\end{array}$ & 1 & 2 & 3 & 4 & 5 \\
\hline 10 & $\begin{array}{l}\text { Menurut Anda, apakah perusahaan logistik } \\
\text { sudah selalu berusaha memenuhi kepuasan } \\
\text { kepada masyarakat? }\end{array}$ & 1 & 2 & 3 & 4 & 5 \\
\hline 11 & $\begin{array}{l}\text { Menurut Anda, apakah perusahaan logistic ini } \\
\text { sudah berusaha meningkatkan pangsa pasar } \\
\text { dalam industri transportasi darat? }\end{array}$ & 1 & 2 & 3 & 4 & 5 \\
\hline
\end{tabular}

Dalam kuesioner penekanannya lebih kepada pelayanan distribusi barang logistic dengan menggunakan warehouse management system yang selalu di up-grade untuk kepuasan pelanggan, dimana logistic sampai pada tepat waktu sesuai pemesanan dan tentunya juga dengan adanya online system agar barang logistic dapat di pantau keberadaannya sertasudah sampai mananya barang logistic tersebut. 


\subsection{Kerangka Penelitian}

\section{Jenis dan Sumber Data}

- Jenis Data, (1) Data Kualitatif adalah data yang dihimpun berdasarkan cara-cara yang melihat suatu objek penelitian. Data semacam ini lebih melihat kepada proses daripada hasil karena didasarkan pada deskripsi proses dan bukan pada perhitungan matematis. Data yang diperoleh seperti jumlah barang yang disimpan digudang lebih banyak dari kapasitasnya. (2) Data Kuantitatif adalah data yang berbentuk angka atau bilangan. Sesuai dengan bentuknya serta data kuantitatif dapat diolah atau dianalisis menggunakan teknik perhitungan matematika ataustatistika. Data yang diperoleh seperti pegawai yang sudah mematuhi SOP perusahaan sekitar $85 \%$.

- Sumber data, (1) Data Primer adalah data yang diperoleh langsung dari responden atas perusahaan yang disebut juga sebagai data asli atau data baru. Data diperoleh dengan melakukan observasi, wawancara dan penyebaran kuesioner. Data yang diperoleh seperti riset pada karyawan dan kepuasan pelanggan pada PT. CEVA Logistics. (2) Data Sekunder adalah data yang diperoleh atau dikumpulkan dari berbagai sumber yang telah ada yang dapat digunakan sebagai dasar penunjang dalam menganalisis masalah-masalah yang menjadi pembahasan dalam karya ilmiah ini. Data sekunder yang diperoleh seperti data company profile, data administrative, dan database komersial perusahaan.

\section{Populasi dan sampel}

- Populasi, Menurut Sugiyono (2016: 90) populasi adalah generalisasi yang terdiri atas: obyek dan subyek dalam mengembangkan kualitas atau mutu dan karakteristik tertentu yang ditetapkan oleh peneliti untuk dipelajari dan ditarik kesimpulan. Dalam penelitian ini yang menjadi objek penelitian adalah seluruh karyawan divisi warehouse PT. CEVA Logistics yang berjumlah 30 orang.

- Sampel adalah bagian dari jumlah dan karakteristik yang dimiliki oleh populasi tersebut, Menurut Sugiyono (2016: 96) sampling jenuh adalah teknik penentuan sampel bila semua anggota populasi digunakan sebagai sampel. Populasi karyawan divisi warehouse sebanyak 30 orang, karena populasi kurang dari 100 maka teknik pengambilan sampel dengan sampling jenuh yang diambil keseluruhan dari populasi untuk sampel. Menurut Sugiyono (2016 : 237) regresi sederhana didasarkan pada hubungan fungsional ataupun kausal satu variable independen $(\mathrm{X})$ dengan satu variabel dependen (Y). Persamaan umum regresi linier sederhana Sugiyono (2016 : 237-239) adalah:

i. Koefisien Korelasi

Menurut Sugiyono (2016 : 212) Korelasi merupakan alat untuk mengetahui derajat hubungan antara variable bebas $(\mathrm{X})$ dengan variable terikat $(\mathrm{Y})$.

Rumus yang digunakan Korelasi Pearson Product Moment ( r )

$$
r=\frac{n\left(\sum x y\right)-\left(\sum x\right)\left(\sum y\right)}{\sqrt{\left.\left\{n\left(\sum x^{2}\right)-\left(\sum x\right)^{2}\right\} n\left(\sum y^{2}\right)-\left(\sum y\right)^{2}\right\}}}
$$

Keterangan :

$$
\begin{aligned}
\mathrm{r} & =\text { Koefisien Korelasi } \\
\mathrm{X} & =\text { Variabel Bebas } \\
\mathrm{Y} & =\text { Variabel Terikat } \\
\mathrm{n} & =\text { Jumlah Sampel } \\
\Sigma & =\text { Jumlah Data }
\end{aligned}
$$


Tabel 2. Interpretasi Koefisien Korelasi

\begin{tabular}{|l|l|}
\hline Interval Koefisien & Tingkat Hubungan \\
\hline $0,00-0,199$ & Sangat Rendah \\
$0,20-0,399$ & Rendah \\
$0,40-0,599$ & Sedang \\
$0,60-0,799$ & Kuat \\
$0,80-1,000$ & Sangat Kuat \\
\hline
\end{tabular}

ii. Koefisien Penentu

Menyatakan besar kecilnya sumbangan variabel bebas (x) terhadap variabel terikat (y) di tentukan dengan koefisien determinan/ penentu.

Rumus koefisien penentu :

$$
K P=r^{2} \times 100 \%
$$

Keterangan :

$$
\begin{aligned}
& \mathrm{KP}=\text { Nilai Koefisien Determinan/Penentu } \\
& \mathrm{r}=\text { Nilai Koefisien }
\end{aligned}
$$

iii. Uji Hipotesis

Uji ini dilakukan dengan cara membandingkan besaran nilai thitung terhadap ttabel. Perumusan Hipotesis menggunakan hipotesis awal dengan $\rho$ (rho) yaitu :

H0: $\rho=0$, artinya tidak ada pengaruh antara variabel $X$ dan variabel $Y$.

Ha $: \rho \neq 0$, artinya terdapat pengaruh antara variabel $X$ dan variabel $Y$. Untuk mencari nilai $t$ hitung dan untuk menguji hipotesis tersebut digunakan rumus sebagai berikut:

$$
t=\begin{aligned}
& r \sqrt{n}-2 \\
& \sqrt{1-r^{2}}
\end{aligned}
$$

Sedangkan untuk mencari nilai ttabel digunakan tabel distribusi t pada $: \alpha=0,05 ; \mathrm{dk}=\mathrm{n}-2$

Keterangan :

$t=$ thitung yang selanjutnya dikonsultasikan dengan ttable

$r=$ Koefisien Korelasi

$n=$ Jumlah Sampel Ketentuan :

Bila thitung > ttabel, maka Ha diterima dan Ho ditolak, artinya terdapat hubungan variabel $\mathrm{X}$ dengan variabel Y.

Bila thitung < ttabel, maka Ha ditolak dan Ho diterima, artinya tidak terdapat hubungan variable $\mathrm{X}$ dengan variable $\mathrm{Y}$.

Hal ini dapat digambarkan sebagai berikut :

\section{Gambar 1 Kurva Distribusi Normal Uji Hipotesis}

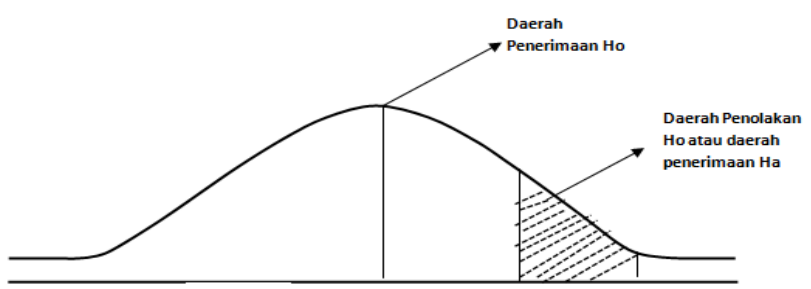

Sumber: Sugiyono (2016: 191) 


\section{HASIL PEMBAHASAN}

Tabel 3 Rekapitulasi Variabel X (Warehouse Management System)

\begin{tabular}{|c|c|c|c|c|c|c|c|c|c|}
\hline \multirow{2}{*}{ No. } & \multirow{2}{*}{ Pernyataan } & SS & ST & $\mathbf{R R}$ & TS & STS & \multirow{2}{*}{$\sum$} & \multirow{2}{*}{ Bobot } & \multirow[t]{2}{*}{-} \\
\hline & & 5 & 4 & 3 & 2 & 1 & & & \\
\hline 1 & $\begin{array}{l}\text { Perusahaan memiliki sistem } \\
\text { management gudang. }\end{array}$ & 13 & 17 & 0 & 0 & 0 & 30 & 133 & 4,4 \\
\hline 2 & $\begin{array}{l}\text { Sistem manajemen gudang selama ini } \\
\text { berjalan dengan efektif. }\end{array}$ & 18 & 12 & 0 & 0 & 0 & 30 & 138 & 4,6 \\
\hline 3 & $\begin{array}{l}\text { Penerapan sistem manajemen gudang } \\
\text { membantu untuk mencapai tujuan } \\
\text { perusahaan. }\end{array}$ & 15 & 13 & 2 & 0 & 0 & 30 & 133 & 4,4 \\
\hline 4 & $\begin{array}{l}\text { Jumlah pallet di gudang mencukupi } \\
\text { untuk menyimpan persediaan. }\end{array}$ & 18 & 12 & 0 & 0 & 0 & 30 & 138 & 4,6 \\
\hline 5 & $\begin{array}{l}\text { Pallet selalu dalam keadaan baik dan } \\
\text { terawat. }\end{array}$ & 12 & 16 & 2 & 0 & 0 & 30 & 130 & 4,4 \\
\hline 6 & $\begin{array}{l}\text { Adanya pemeliharaan, perawatan dan } \\
\text { perbaikan secara rutin pada forklift. }\end{array}$ & 13 & 15 & 2 & 0 & 0 & 30 & 131 & 4,4 \\
\hline 7 & $\begin{array}{l}\text { Penggunaan forklift sesuai dengan } \\
\text { ketentuan SOP. }\end{array}$ & 15 & 13 & 2 & 0 & 0 & 30 & 133 & 4,4 \\
\hline 8 & $\begin{array}{l}\text { Adanya pemeriksaan forklift secara } \\
\text { keseluruhan sebelum dioperasikan. }\end{array}$ & 12 & 17 & 1 & 0 & 0 & 30 & 131 & 4,3 \\
\hline 9 & $\begin{array}{l}\text { Terdapat pengaturan rak untuk setiap } \\
\text { jenis barang. }\end{array}$ & 13 & 17 & 0 & 0 & 0 & 30 & 133 & 4,4 \\
\hline 10 & $\begin{array}{l}\text { Petugas gudang wajib mengetahui tata } \\
\text { letak barang dengan kemasan yang } \\
\text { hampir sama. }\end{array}$ & 17 & 13 & 0 & 0 & 0 & 30 & 137 & 4,6 \\
\hline & Total & 146 & 145 & 9 & $\mathbf{0}$ & $\mathbf{0}$ & 300 & 1337 & 4,5 \\
\hline
\end{tabular}

Sumber: Hasil Kuesioner (diolah penulis)

Keterangan:

$$
\begin{array}{ll}
\text { SS } & =\text { Sangat Setuju } \\
\text { ST } & =\text { Setuju } \\
\text { RR } & =\text { Ragu-ragu } \\
\text { TS } & =\text { Tidak Setuju } \\
\text { STS } & =\text { Sangat Tidak Setuju }
\end{array}
$$


Berdasarkan data rekapitulasi variabel warehouse management systemdi atas, dapat dilihat pernyataan pertama tertinggi yang berbunyi "Sistem manajemen gudang selama ini berjalan dengan efektif", terlihat dari bobot dan rata-rata hasil perhitungan penelitian sebesar $138(4,6)$ dan terdapat pernyataan kedua tertinggi yang berbunyi "Petugas gudang wajib mengetahui tata letak barang dengan kemasan yang hampir sama" terlihat dari bobot dan rata-rata $137(4,5)$. Hal ini menunjukkan bahwa sistem manajemen gudang selama ini berjalan dengan efektif merupakan salah satu solusi untuk meningkatkan kelancaran pendistribusian barang serta petugas gudang wajib mengetahui tata letak barang dengan kemasan yang hampir sama yang berdampak pada produktivitas kelancaran distribusi barang. Mengenai warehouse management system, sebagian besar menyatakan sangat setuju yaitu sebesar $146(48,67 \%)$, kemudian untuk responden yang menyatakan sangat setuju sebesar 145 (15\%) dan responden yang menyatakan ragu-ragu sebesar 9 (3\%). Artinya warehouse management system pada PT. CEVA Logistics sudah mempunyai distribusi produk barang yang cukup tinggi.

Tabel 4 Rekapitulasi Variabel Y (Kelancaran Distribusi)

\begin{tabular}{|c|c|c|c|c|c|c|c|c|c|}
\hline \multirow{2}{*}{ No. } & \multirow{2}{*}{ Pernyataan } & SS & ST & $\mathbf{R R}$ & TS & STS & \multirow{2}{*}{$\Sigma$} & \multirow{2}{*}{ Bobot } & \multirow[t]{2}{*}{-} \\
\hline & & 5 & 4 & 3 & 2 & 1 & & & \\
\hline 1 & $\begin{array}{l}\text { Terdapat fasilitas fisik yang memadai } \\
\text { untuk distribusi barang. }\end{array}$ & 9 & 17 & 4 & 0 & 0 & 30 & 125 & 4,2 \\
\hline 2 & $\begin{array}{l}\text { Terdapat pemeliharaan dan perawatan } \\
\text { terhadap fasilitas yang ada di } \\
\text { gudang. }\end{array}$ & 11 & 16 & 3 & 0 & 0 & 30 & 128 & 4,3 \\
\hline 3 & $\begin{array}{l}\text { Terdapat perawatan dan perlindungan } \\
\text { untuk persediaan yang ada di gudang. }\end{array}$ & 9 & 14 & 6 & 1 & 0 & 30 & 121 & 4,0 \\
\hline 4 & $\begin{array}{l}\text { Tersedianya kartu persediaan untuk } \\
\text { mencatat dan mengetahui jumlah } \\
\text { persediaan di gudang. }\end{array}$ & 9 & 17 & 2 & 2 & 0 & 30 & 123 & 4,1 \\
\hline 5 & $\begin{array}{l}\text { Adanya pemeriksaan jumlah } \\
\text { persediaan baik di sistem dan aktual. }\end{array}$ & 12 & 17 & 1 & 0 & 0 & 30 & 131 & 4,4 \\
\hline 6 & $\begin{array}{l}\text { Menggabungkan pengiriman dengan } \\
\text { tujuan yang berbeda. }\end{array}$ & 8 & 19 & 3 & 0 & 0 & 30 & 125 & 4,2 \\
\hline 7 & $\begin{array}{l}\text { Kendaraan mencukupiuntuk } \\
\text { mendistribusikan produk. }\end{array}$ & 8 & 21 & 1 & 0 & 0 & 30 & 127 & 4,2 \\
\hline 8 & $\begin{array}{l}\text { Pemesanan barang dilakukan secara } \\
\text { online. }\end{array}$ & 11 & 18 & 1 & 0 & 0 & 30 & 130 & 4,3 \\
\hline 9 & $\begin{array}{l}\text { Adanya laporan tentang permasalahan } \\
\text { dalam pendistribusian barang. }\end{array}$ & 5 & 6 & 14 & 5 & 0 & 30 & 101 & 3,4 \\
\hline 10 & $\begin{array}{l}\text { Perusahaan membangunhubungan } \\
\text { baik dengan customer. }\end{array}$ & 11 & 18 & 1 & 0 & 0 & 30 & 130 & 4,3 \\
\hline & Total & 93 & 163 & 36 & 8 & 0 & 300 & 1241 & 4,1 \\
\hline
\end{tabular}

Sumber: Hasil Kuesioner (diolah penulis)

Keterangan:

$$
\begin{array}{ll}
\mathrm{SS} & =\text { Sangat Setuju } \\
\mathrm{ST} & =\text { Setuju } \\
\mathrm{RR} & =\text { Ragu-ragu }
\end{array}
$$




$$
\begin{aligned}
& \text { TS }=\text { Tidak Setuju } \\
& \text { STS }=\text { Sangat Tidak Setuju }
\end{aligned}
$$

Berdasarkan data rekapitulasi diatas, dapat dilihat bahwa variabel kelancaran distribusi lebih fokus pada pernyataan yang berbunyi "Adanya pemeriksaan jumlah persediaan baik di sistem dan aktual", terlihat dari bobot dan rata-rata hasil perhitungan penelitian sebesar $131(4,4)$. Hal ini menunjukkan bahwa dilakukan pemeriksaan pada jumlah persediaan baik di sistem dan actual agar pendistribusian barang berjalan dengan lancar.

Dari hasil keseluruhan pendapat responden pada tabel IV.26 yaitu mengenai kelancaran distribusi, sebagian besar menyatakan sangat setuju yaitu sebesar 163 (54,33\%), kemudian untuk responden yang menyatakan sangat setuju sebesar $93(31 \%)$, responden yang menyatakan ragu-raggu sebesar $36(12 \%)$ dan untuk responden yang menyatakan ragu-ragu sebesar 8 (2,67\%). Artinya kelancaran ditribusi pada PT. CEVA Logistics sudah berjalan dengan lancar.

\section{KESIMPULAN}

Warehouse management system dalam usaha pengelolaan gudang PT. CEVA Logistics menunjukkan bahwa sebagian besar karyawan menyatakan setuju dengan belum optimalnya warehouse management system, adanya sistem manajemen gudang yang selama ini berjalan dengan efektif merupakan salah satu solusi untuk meningkatkan pengelolaan dalam gudang serta ditambah dengan adanya pemeriksaan jumlah persediaan baik di sistem dan aktual untuk memperlancar pendistribusian produk dengan melalui pelayanan sistem pergudangan yang selalu dalam pengawasan apakah sistem penditribusian dan pergudangannya sudah cocok sesuai nama-nama barang logistic tersebut dan lokasi pendistribusiannya.

Adanya nilai terendah pada pernyataan variabel warehouse management system yang berbunyi "Pallet selalu dalam keadaan baik dan terawat" dan pernyataan pada variabel kelancaran distribusi yang berbunyi "Adanya laporan tentang permasalahan dalam pendistribusian barang" menunjukkan masih perlunya diadakan evaluasi untuk meningkatkan kelancaran distribusi. Dengan melalui kemasan yang baik sesuai barang logsitik yang didistribusi maka distribusai pun tidak menjadsi suatu hambatan.

Pengaruh warehouse management system terhadap kelancaran distribusi produk Electrolux pada PT. CEVA Logistics berdasarkan hasil uji hipotesis diperoleh nilai thitung sebesar 5,0920 dan nilai ttabel 1,701 berarti thitung $>$ ttabel $=5,0920>1,701$. Karena thitung lebih besar daripada ttabel maka, Ho ditolak dan Ha diterima, artinya ada pengaruh yang positif antara variabel $\mathrm{X}$ (warehouse management system) terhadap variabel Y (kelancaran distribusi) sebesar 0,6934. Dengan pengaruh positif tersebut diatas maka diharapkan pendistribusian barang logistic tepat waktu dan dalam kosndi baik.

\section{DAFTAR PUSTAKA}

[1] Widjaja Tunggal Amin; Manajemen Logistik dan Supply Chain Management (Management Rantai Pasok), Harvindo, Jakarta, 2009.

[2] Kodrat David Sukardi; Manajemen Distribusi, Graha Ilmu, Yogyakarta, 2009. John Warman; Manajemen Pergudangan, PPM Manajemen, Jakarta, 2016.

[3] M. Nur Nasution; Manajemen Transportasi, Edisi Ketiga, Ghalia Indonesia, Bogor, 2008.

[4] Malayu Hasibuan; Manajemen Dasar, Pengertian dan Masalah, PT. Bumi Aksara, Jakarta, 2007.

[5] Ratih Hendayani; Mari Berkenalan Dengan Manajemen Logistik, ALFABETA, Bandung, 2011.

[6] Ricky Martono; Manajemen Logistik Terintegrasi, PPM Manajemen, Jakarta, 2015.

[7] Stephen P Robbins dan Mary Coulter; Manajemen, Jilid I, Edisi Kesepuluh, Erlangga, Jakarta, 2010.

[8] Soebagio; Manajemen Logistik, Stmt Trisakti, Jakarta, 2000. 
[9] Sugiyono, Metode Penelitian Administrasi Metode R\&D, Alfabeta, Bandung, 2016. Tim Penyusun Stmt Trisakti ; Kamus Terpopuler Transportasi dan Logistik, Erlangga, Jakarta, 2012.

[10] George R Terry, dan Leslie W. Rue ; Dasar-Dasar Manajemen, PT. Bumi Aksara, Jakarta,2005.

[11] Usman Efendi ; Asas Manajemen, PT. Raja Grafindo Persada, Jakarta, 2011.

[12] Widiyanto ; Budiman Tenaka ; Panduan \& Direktori Logistik Indonesia, PPM \& Asosiasi Logistik Indonesia, Jakarta, 2011.

[13] Willem Siahaya; Supply Chain Management, In Media, Jakarta, 2013.

[14] www.academia.edu/22429320/MataKuliah_Manajemen_Gudang_WAREHOUSE_MANAGEMENT $\underline{\text { SYSTEM_Oleh }}$

[15] https://library.binus.ac.id/eColls/eThesisdoc/Bab2/2012-1-01350-SI\%20Bab2001.pdf 